\title{
The Students' Viewpoints at Muhammadiyah University of Enrekang During Covid-19
}

\author{
Mustakim $^{1}$, Putri Dewi ${ }^{2}$, Yusuf Durachman ${ }^{3}$ \\ \{kimchangi00@gmail.com¹, dewidewi040603@gmail.com², yusuf_durachman@uinjkt.ac.id\} \\ Universitas Muhammadiyah Enrekang ${ }^{1}$, STAI DDI Parepare ${ }^{2}$, UIN Syarif Hidayatullah Jakarta ${ }^{3}$
}

\begin{abstract}
The aim of this research is to find out how students' viewpoints about digital learning during the Covid-19 pandemic. Its specific goal is to determine the types of applications, supporting variables, and resistor factors that are included in online lectures. The descriptive survey analysis approach was used to perform this study. The data collection method used is a questionnaire. The results indicate that students get internet access in a variety of locations: $48.8 \%$ of students replied at home, $22.6 \%$ at home with a strong family internet network, $9.7 \%$ of students answered that they had to drive long ways to reach a network, and there were even those who answered in the farms and mountains. Smartphones and tablets are among the mobile equipment used by students to attend online lectures. There are 77,4 percent of students who believe that using chat via WA is the most successful application, and there are 6,5 percent of students who disagree. Only $9.7 \%$ of students used Learning Management System (LMS). When questioned if they were pleased with this e learning application scheme as a whole during online lectures during the covid19 pandemic, $45.2 \%$ of students responded dissatisfied, $22.6 \%$ of students responded satisfied, and $16.1 \%$ of students responded quite dissatisfied and quite satisfied. Face-toface lectures are preferred by almost all students over online lectures.
\end{abstract}

Keywords: Perception, Online Learning, Pandemic, Covid-19.

\section{Introduction}

The effect of the pandemic covid-19 in 2020 in Indonesia has begun to impede the world of education; the central government has issued a directive to local governments to dismiss all educational institutions. This is done to sever the corona virus's chain of transmission. It is assumed that all educational establishments would not carry out regular operations, thus limiting the dissemination of Covid-19. Many countries have already been subjected to the disease Covid -19 , so a regime of lockout or quarantine has been implemented to limit the contact of the many individuals who may transmit the corona virus. The transmission of the corona virus initially had an effect on the global economy, but now the impact is felt by the world of schooling.

Many nations, like Indonesia, have followed the wisdom of dismissing all educational practices. Who will be unable to carry out the instructional phase in a face-to-face environment? In the case of Covid-19, which is online learning for school children, online college, national examination dispensed, UTBK SBMPTN 2020 in retreat, and the implementation of SNMPTN is still in the assessment, the government adopted the Sevima (2020) policy in the field of education. According to Nailul Mona (2020), the corona virus disease, also known as covid-19, 
is a new form of virus discovered in 2019 that has never been linked to a human infection.

Universitas Muhammadiyah Enrekang released a circular letter no:12/II.3.AU/F/2020 on preventing the dissemination of the corona virus in the Universitas Muhammadiyah Enrekang due to an increase in the number of positive patients in Covid-19 and the spread of the corona virus in Indonesia. The progress of improvements in the status of covid-19 infection events pandemic, the Universitas Muhammadiyah Enrekang stipulates the following matters. Universitas Muhammadiyah Enrekang has planned a research extension at home beginning April 21st, 2020, primarily for events on campus.

This research is done by researchers because of the spread of the covid-19 pandemic around the world and resulted in the government taking a policy to change the learning process to an online system. Since STKIP Muhammadiyah Enrekang has recently became Universitas Muhammadiyah Enrekang, there were a number of challenges that teachers and students faced in implementing an online learning scheme, including how to use the program in the online learning phase, quota restrictions for students, and the use of an interference network.

In Indonesia, the advancement of information and communication technology has had a significant impact on education, especially in the learning process. A change in the learning environment indicates this pattern, with encounters between educators and students taking place not only through face-to-face interactions but also through communication channels such as computers, the phone, and so on. E-learning, according to Hartley (2001), is a form of teaching and learning in which teaching materials are delivered to students through internet media, the internet, or other computer network media. This is to support the learning services that students can use. A learning framework specification is also accessible, which each learning participant may learn and understand. According to Nichols (2008), e-learning is described as the use of digital media to empower pedagogy. This implies that e-learning can be described as education that is funded entirely by digital technologies. To put it another way, the e-learning process is aided by digital technology. Technology here does not just refer to the internet; it also includes CD-ROM and DVD-ROM technologies (Solichin, 2009).

Online learning is learning that uses the benefits of the internet as a media intermediary between the instructors and students to effectively connect. Online learning may make use of self-contained instructional resources that can be downloaded by anybody, at any time, over the internet. E-learning is a type of information technology used in the field of education that takes place in cyberspace. The word e-learning refers to the conversion of a learning activity that takes place in schools or colleges into a multimedia medium that can be accessed through the internet (Munir, 2009). Seok (2008) notes that e-learning is a modern type of pedagogy for learning in the 21 st century. E-teachers are e-learning instructional designers, conversation facilitators, and topic matter specialists. The use of e-learning for online learning is now very simple thanks to learning module management systems like Moodle, which are simple to install and maintain.

Students at Universitas Muhammadiyah Enrekang, specifically those in the department of English education, must learn and improve science and technology in order to become educators. Educators aim to enhance the learner's preparation and execution in order to achieve higher-quality instruction. Since there are too many apps that can be used to aid the learning process online, Nextrem has compiled a list of the top three that you can use to train from home: Zoom Cloud Meeting, Skype, and WhatSapp (Nextrem, 2020).

\section{Research Methods}


The research was done using a qualitative descriptive approach. Sukmadinata (2016) explained that qualitative analysis is to identify and to interpret patterns, occurrences, social interactions, behaviors, values, interpretation, thinking of individuals individually or in groups. Qualitative descriptive experiments are the least theoretical of any of the qualitative approaches to science. Furthermore, when compared to other qualitative approaches, qualitative descriptive studies are the least encumbered by a pre-existing theoretical or philosophical commitment. Phenomenology, grounded theory, and ethnography, for example, are all concerned with unique analytical concepts that emerged from specific disciplinary traditions.

\section{Findings and Discussions}

The aim of this research is to find out how students felt about digital or online learning during the Covid-19 pandemic. Its specific goal is to determine the types of applications, supporting variables, and resistor factors that are included in online lectures. University LMS, Whatsapp, Google Classroom, Zoom, and other forms of online learning applications were commonly used during the Covid-19 pandemic. Based on the outcome of questionnaire number $8,64,5$ percent chose Whatsapp as a media promoting digital learning since it was simple to get the internet network and not a ton of taking an internet quota.

According to the results of questionnaire number $9,67,7 \%$ of students chose Whatsapp community as a digital learning medium. According to the results of Question 13 of the survey, 77,4 percent of students believed the WA community was a successful online learning application during the Covid-19 pandemic. There were 9,7 percent of students who answered Google Classroom, 6,5 percent who answered University LMS, and one student who answered Zoom and video offline. Why should more students use WhatsApp for online learning? WhatsApp can deliver text messages, voice messages, and photographs, as well as different types of images or illustrations, files, and learning content records, and it can conveniently connect to the internet network. According to Prajana (2020), students were very happy with the media WhatsApp group chats because it did not consume a lot of quota, the network was more stable, could access from anywhere, could repeat material back, and was more effective and efficient as a whole, one of the applications that develops for education and is in high demand in this era.

The Google Classroom software works similarly to WhatsApp, except it was designed to be used for conversations and submitting tasks to make things simpler and more organized. The university's LMS framework was used to further build and upgrade the university's system. Support classroom teaching programs with ease, pace, and practicality. Although Google meet or zoom was used for face-to-face online meetings so that teachers would see the faces of students who pay attention to the instructor when providing examples of the content, it must be with a good internet network. The usage of online learning using Zoom cloud meetings has the benefit of allowing students to communicate directly with lecturers and teaching resources, but it has the disadvantage of wasting power and being less successful while more than 20 students are present.

The provision of facilities and resources for studying, such as HP and laptops, was a supportive factor in digital learning during the Covid-19 pandemic, according to the results of the questionnaire number 5. 45,2 percent of students responded that they were able to study digitally. In the journal La Ode Anhusadar (2020) that students opinions regarding online lectures are varied, as articulated by Wa Ode Meilin Saputri that online lectures are delivered 
utilizing communication media such as HP or Laptop which are online. It reveal that 58 or 96,6 percent students used HP in taking online lectures and there were 2 or 3,4 percent students use laptop in taking online lectures. And also it can be confirmed by the opinion of Purwanto et al. (2020) reported that this facility was very necessary for the smoothness of the teaching and learning method, such as tablets, computers or HP which was making it simpler for teachers to have teaching and learning materials online.

According to the results of questionnaire number two, 35.5\% of students responded that they had a sufficient internet network during the online learning process. Aside from that, the existence of internet quotas and an effective internet network are other supporting factors that influence online learning. Purwanto et al (2020) believe that internet quotas and secure or strong networks are other backers of online learning. Students can find internet networks in many ways, such as their own houses, family homes, on mountains, in gardens, long trips etc. Based on the outcome of questionnaire number 3 , there were 48,4 percent of students who replied at home. There were 51,6 percent of students saying that online learning was very simple to use based on the questionnaire number 14. Since lecturers can have lecture materials in the form of files, photographs, or text, $54,8 \%$ of students who responded to questionnaire number 18 said that teaching materials were of high quality. Even if there is no internet connection, lecturers can access it.

The resistor factors in digital learning during the Covid-19 Pandemic can be seen in the results of questionnaire number 12 , where $90 \%$ of students responded that there were barriers during the online learning time.According to the results of questionnaire number $4,48.4 \%$ of students at Universitas Muhammadiyah Enrekang said it was challenging to shift the learning structure from classroom to online since online learning was more complex than regular learning, not to mention that internet quotas would be accessible, and this was the biggest challenge that students faced.

According to the results of questionnaire number 6, 45,2 percent of students said they were not comfortable with online learning because they were not prepared to take it from the outset, with the issue that they barely used internet technologies and that some students did not know how to use the internet at all. The next response was 35,5 percent of students who answered that they did not have internet data because current quota rates were very high during the pandemic. Another 19,4 percent claimed that they do not have access to the internet since they reside in a village with poor internet connectivity. According to the questionnaire number 11, 48,4 percent of students answered Rp.50.000 to Rp.100.000, while 19,4 percent answered Rp.200.000. The challenge faced was restrictions on funding studying online.

Students announce that they are taking part in online learning. They have to pay quite a fortune to purchase internet data quota, though online conversations via instant messaging applications do not need much quota. On average, students pay Rp.100,000 to Rp.200.000 each week, depending on the cellular provider used. The cost of utilizing video conferencing for online learning was very large (Naserly, M. K., 2020). According to the results of questionnaire number 7, 29\% of students do not know about government learning support systems such as internet quotas and learning sites such as learning home. There were also 64,5 percent of students who answered less on questionnaire number 10, which specifies whether learning tasks are organized according to a timetable or not.

According to the results of Question 15 about how lecturers and students communicate utilizing the online method, students react less. In response to question $16,38,7 \%$ of students said they were less involved in online learning. According to the results of Question No. 17, 45,2 percent of students believe that online learning can be used to practice learning objectives, such as seminars, seminars, practicums, and CSL, since they believe that the implementation of 
online learning that they got was just based on giving assignments and provided so little content.

According to the results of Question 18 of the survey, $54,8 \%$ of students believe that quality teaching resources are delivered during online learning because lecturers may include lecture material in the form of files, photographs, or written or text. In response to question 19 on whether you were pleased with this e-learning scheme as a whole, 45,2 percent of students said they were not satisfied with online learning because it began with internet network constraints, internet quotas, learning resources, and lecturer-presented teaching materials that were not qualified. When students are given a large number of assignments in a short amount of time, they are likely to get frustrated, and their academic process can suffer as a result.

\section{Conclusions}

According to the findings of the study, students have a positive attitude toward digital learning. E-learning was used by 64,5 percent of the 31 students who expressed an interest in learning. Students appear to favor using the WhatsApp program. E learning is supported by a number of variables, including the availability of learning machines such as HP notebooks, sufficient internet quotas, and an adequate internet network. However, there are many barriers to online instruction, including the expense of Internet quotas, the difficulty of running the Internet, and the difficulty of connecting to the Internet. Since lecturers often offer more assignments than describing the material, there is less interest in student online learning during the Covid-19 pandemic. Students are still sluggish to grasp the content, despite the fact that the lecturer submitted the lecture material via file. However, this was not the case while researching face-to-face rather than practicing alone. Almost all students prefer face-to-face lectures to online lectures. According to the results of Question 19 regarding user interaction with the elearning program framework as a whole, $45.2 \%$ of students said they were dissatisfied. As a result, the researchers can infer that during the Covid-19 pandemic, students were more likely to be satisfied with face-to-face instruction than online learning.

\section{References}

[1] Anhusadar. (2020). Students perceptions PIAUD to online lecture during the covid-19 pandemic. Journal of Islamic Early Childhood Education.

[2] Holzberger, D., Philipp, A., \& Kunter, M. (2013). How teachers' self-efficacy is related to instructional quality: A longitudinal analysis. Journal of educational psychology, 105(3), 774-786.

[3] Isabelle. (2017). Advantage and disadvantages of e-learning . https://elearningindustry.com/advantages -and-disadvantages-of-elearning.

[4] Lazarowitz., R., \& Penso, S. (1992). High school students' Difficulties in learning biology concepts. Journal of Biological Education, 26, 215-224.

[5] Ming-Hung Lin, Huang-Cheng Chen, Kuang-Sheng Liu. (2017). A Study of the Effects of Digital Learning on Learning Motivation and Learning Outcome. EURASIA Journal of Mathematics Science and Technology Education.

[6] Mona, N. (2020). Konsep isolasi dalam jaringan sosial untuk meminimalisasi efek contagious (kasus penyebaran virus corona di Indonesia). Jurnal sosial humaniora terapan., 2(2), 117-125.

[7] Mustakim Mustakim , Elihami Elihami, Musdalifah Musdalifah, Baharuddin Baharuddin , Emirati Emirati. (2020). Japanese Non-Verbal Education Communication by the Main Characters in the Novel of Totto-Chan and the Light on Curtain of Sakura: An Analysisofkinesics. Journal of Critical Reviews, 7 (9), 618-622. doi:10.31838/jcr.07.09.122 
[8] Mustakim, M., Doloh, S., \& Busa, Y. (2020). International Community Service Program Model for Teacher Prospective Students at STKIP Muhammadiyah Enrekang. MAJESTY JOURNAL, 2(1), 31-39. https://doi.org/10.33487/majesty.v2i1.330

[9] Mustakim, M., \& Salman, S. (2019). Character Building Based on Local Culture. Edumaspul: Jurnal Pendidikan, 3(2), 22-30. https://doi.org/10.33487/edumaspul.v3i2.133

[10] Naserly, M. K. (2020). Implementasi Zoom, Google Classroom , dan WhatsApp Group dalam mendukung pembelajaran daring (online) pada mata kuliah bahasa Inggris lanjut (studi kasus pada 2 kelas semester 2, jurusan administrasi bisnis, fakultas ekonomi dan bisnis, Universitas Bina Sa. Aksara Public, $4(2), 155-165$

[11] Nextren. (2020). 3-aplikasi-untuk-kuliah-online-selama-masa-karantina-virus-corona? Retrieved from https://nextren.grid.id/read/012065339/3-aplikasi-untuk-kuliah-online-selama-masa-karantina-virus -corona-?page=all.

[12] Prajana, A. (2017). Pemanfaatan aplikasi WhatsApp untuk media pembelajaran dalam lingkungan Uin Ar-Raniry Banda Aceh. Cyberspace: jurnal pendidikan teknologi informasi, 1(2), 122. https://doi.org/10.22373/cs.vli2.1980

[13] Saputro, F. B., Somantri, M., \& Nugroho, A. (2017). Pengembangan sistem kuliah online Universitas Diponegoro untuk antar mahasiswa pada perangkat bergerak berbasis android. Pengembangan sistem kuliah online Universitas Diponegoro untuk antar muka mahasiswa pada perangkat bergerak berbasis android, 19(1), 15-21. https://doi.org/10.12777/transmisi.19.1.15.21.

[14] Sevima. (2020). 5 kebijakan pendidikan masa darurat corona. Retrieved from https://sevima.com/5kebijakan-pendidikan-masa-darurat-corona/

[15] Susilo, A. (2020). Corona virus Disease 2019. Department Ilmu Penyakit Dalam. Fakultas Kedokteran Universitas Indonesia - RSUPN dr. Cipta Mangunkusumo, Jakarta.

[16] Sugiyono. (2010). Metode penelitian pendidikan. Bandung: Alfabeta.

[17] Surat edaran Universitas Muhammadiyah Enrekang No: 12/II.3.AU/F/2020. Pencegahan penyebaran virus corona (covid-19) di lingkungan Universitas Muhammadiyah Enrekang.

[18] Sukmadinata, Nana Syaodih. (2016). Metode penelitian pendidikan. Bandung. Remaja Rosdakarya [19] Vickie, Clinton. (2012). Qualitative descriptive research an acceptable design. Pacific Rim International Journal of Nursing Research.

[20] Zhafira, N H., Ertika, Y., \& Chairiyaton. (2020). Persepsi mahasiswa terhadap perkuliahan daring sebagai sarana pembelajaran selama masa karantina Covid-19. Jurnal Bisnis Dan Kajian Strategi Manajemen, 4, 37-45. 